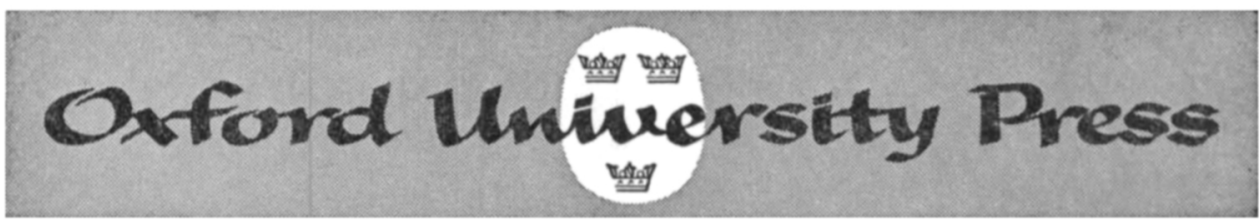

\title{
History of Java
}

By the late Sin Thomas Stamford Raffles. Late in the summer of 1965 Oxford will offer a facsimile reprint of a classic collector's item. First published at the end of the nineteenth century, History of Java is a famous standard work on Java by the renowned founder of Singapore. Illustrated with many beautiful color plates.

Two quarto volumes of 1,000 pages, boxed. $\$ 50.00$ a set

\section{The Administration of Guntur District 1788-1848}

\section{A History of Local Influence on Central} Authority in South India

By Robert E. Frykenberg, University of Wisconsin. Between 1788 and 1848, silent combinations of local groups in Guntur District increased their power at the expense of the State, and British officers lost control of their Indian subordinates. From manuscript sources, Mr. Frykenberg examines this conflict, traces elements of social structure, land control and political functions in a Telugu area, and analyzes traditional institutions and processes of power. 4 maps. $\$ 6.75$

\section{The Development of British Malaya 1896-1909}

By Chat Hon-Chan, University of Malaya. Concerned with the areas of Perak, Selangor, Pahang and Negri Sembilan (known after 1895 as the Federated Malay States), this study emphasizes the administrative and social aspects of Malaya's development. In drawing together such apparently disparate subjects as labor and education, medical research and the rubber industry, tin mining and the development of communications, currency matters and immigration policies, and constitutional reforms, much new and comparatively unknown material is brought to light. Bibliography, 5 maps, 2 appendices, index. Cloth, $\$ 7.35$. Paper, $\$ 4.90$

\section{Government and People in Hong Kong 1841-1962}

\section{A Constitutional History}

By G. B. ENDaCoTT, University of Hong Kong. In this definitive account of the British Crown Colony, the author treats it not only as a case study in British colonial history but also as a settlement with notable contrasts to the rest of Asia. He thoroughly examines the application of British ideas of government to an overwhelmingly Chinese community, its conspicuous absence of political agitation, and the early British attempt to adapt its colonial institutions to meet administrative needs of the British communities in the Treaty Ports. Carrying constitutional developments up through 1962, Mr. Endacott concludes with a prospectus for the future. 14 halftones, 1 map.

$\$ 6.00$

\section{Oxford University Press / New York}




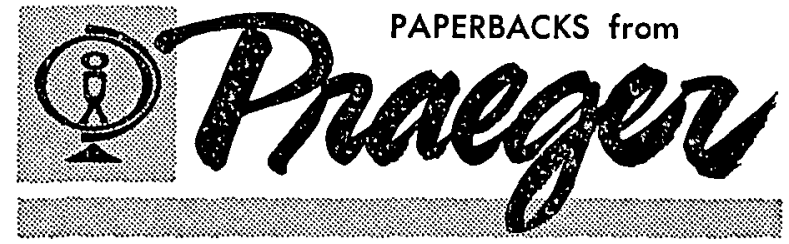

Coming in July

for your fall-semester courses!

TWO INDISPENSABLE BOOKS ON ASIA

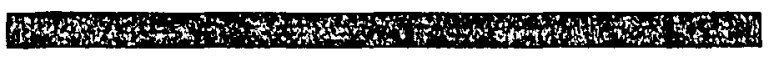

\title{
CHINA:
}

\section{A Short Cultural History \\ by C. P. FitzGerald}

"Probably the best modern one-volume approach in English. ... Written with perspicacity of insight, understanding, and balance, and extremely readable."American Anthropologist. "Concisely planned and brilliantly executed."-The Times Literary Supplement (London). "A perfectly admirable book which . . . contrives to give a just account of the developments of 3,000 years."-The Guardian (Manchester). With 21 photographs, 66 drawings, 19 maps. $\$ 3.95$

\section{INDIA:}

\section{A Short Cultural History by H. G. Rawlinson}

"The reader who wants a compendious account of India's culture will find it in this book."-The Times Literary Supplement. "Particularly significant is the author's handling of India's relations with China, which were firmly fixed in the year 500."-The Christian Science Monitor. "A well written, lucid, thoroughly scientific, and yet enjoyable history of India. . . . Cannot be too highly recommended."-Library Journal. With 70 illustrations, 12 maps. $\$ 3.95$

... and just published

\section{COMMUNIST CHINA'S CRUSADE}

\section{Mao's Road to Power and the New Campaign for World Revolution}

By GUY WINT. Based on Mr. Wint's highly regarded Dragon and Sickle, but largely rewritten and much expanded, this book explains how Mao Tse-tung adapted Communism to China's unique political and social circumstances. $\$ 1.75$

\section{FREDERICK A. PRAEGER, Publishers}

\author{
111 Fourth Avenue, New York, N. Y. 10003
}




\section{MONOGRAPHS OF THE ASSOCIATION FOR ASIAN STUDIES}

\section{Delmer M. Brown, Editor}

I. Money Economy in Japan: A study in the use of coins, by Delmer M. Brown. 1951. vii, 128 pp. Bibliography. Cloth $\$ 2.50$.

II. China's Management of the American Barbarians: A Study of Sino-American Relations, 1841-1861, with documents, by Earl Swisher. 1951. xxi, 844 pp. Glossary, bibliography. Cloth $\$ 7.50$.

III. Leadership and Power in the Chinese Community of Thailand: By G. William Skinner. 1958. xvii, 363 pp., 9 charts. Cloth $\$ 6.50$, Cornell University Press, Ithaca, N. Y.

IV. Siam Under Rama III, 1824-1851: By Walter F. Vella. 1957. viii, 180 pp., 2 illustrations, 4 maps, appendix, bibliography, index. Cloth $\$ 5.00$.

V. The Rise of the Merchant Class in Tokugawa Japan, 1600-1868: An introductory survey, by Charles David Sheldon. 1958. ix, 206 pp. Glossary, bibliography, index. Cloth $\$ 5.00$.

VI. Chinese Secret Societies in Malaya: A survey of the Triad Society from 1800 to 1900 , by L. F. Comber, B.A., F.R.A.S. 1959. viii, 324 pp., 15 illustrations, 1 map in color, 5 maps, bibliography, index. Cloth $\$ 6.50$.

VII. The Traditional Chinese Clan Rules: By Hui-chen Wang Liu. 1959. x, 264 pp., 1 illustration, 50 tables, bibliography. Cloth $\$ 5.50$.

VIII. A Comparative Analysis of the Jajmani System: By Thomas O. Beidelman. 1959. iv, 86 pp., bibliography, index. Cloth $\$ 2.50$.

IX. Colonial Labor Policy and Administration: By J. Norman Parmer. 1959. xii, 294 pp., 2 maps, 9 charts, bibliography, index. Cloth $\$ 6.00$.

X. Banghkaud-A Community Study in Thailand: By Howard Keva Kaufman. 1959. xi, 236 pp., 6 plates, 8 illustrations, glossary, bibliography, index. Cloth $\$ 5.50$.

XI. Agricultural Involution: The Processes of Ecological Change in Indonesia, by Clifford Geertz. The University of California Press. 1963. xx, 176 pp., bibliography, index. $\$ 4.00$.

XII. Maharashta Purana, by Edward C. Dimock, Jr. and Pratul Chandra Gupta. East-West Center Press, 1964. \$5.00.

XIII. Conciliation In Japanese Legal Practice, by Dan Fenno Henderson. 2 Vols. The University of Washington Press, 1964.

XIV. The Malayan Tin Industry to 1914, by Lin Ken Wong. The University of Arizona Press, 1965. \$6.50.

XV. Reform, Rebellion, and The Heavenly Way, by Benjamin F. Weems. The University of Arizona Press, 1965. $\$ 3.75$.

XVI. Korean Literature: Topics and Themes, by Peter H. Lee. The University of Arizona Press, $1965 . \$ 3.75$.

XVII. Ch'oe Pu's Diary: A Record of Drifting Across The Sea, by John Meskill. The University of Arizona Press, 1965. $\$ 4.50$.

XVIII. The British in Malaya: The First Forty Years, by K. G. Tregonning. The University of Arizona Press, 1964. $\$ 4.50$.

XIX. Chiaraijima Village, Land Tenure, Taxation and Local Trade, by William Jones Chambliss. University of Arizona Press, 1965. About $\$ 5.00$.

XX. Shinran's Gospel of Pure Grace, by Alfred Bloom. The University of Arizona Press, 1965. About $\$ 5.00$.

*Nos. I and II and IV through $\mathrm{X}$ are available from the publisher, J. J. Augustin of Locust Valley, New York. 


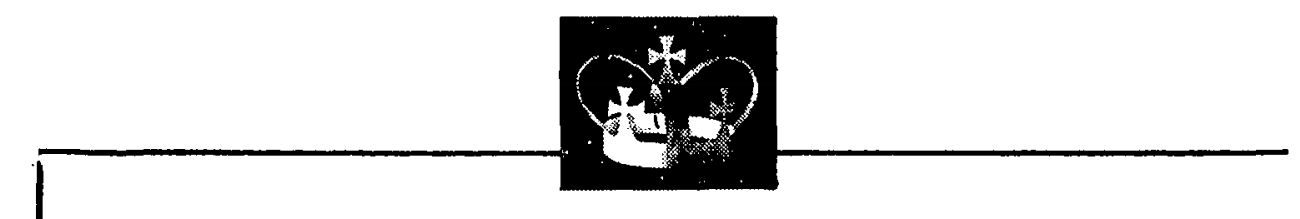

\section{THE MANYŌSHŪ}

Chosen from the oldest and largest of Japanese anthologies and still regarded as one of the highest in quality, this group of 1,000 poems reflects Japanese life and civilization of the seventh and eighth centuries. The poets represented range from sovereigns, princes and courtiers to soldiers and simple folk. Patriotism, religion, court life and rural customs are among the themes treated.

$\$ 12.50$

\section{SU TUNG-P'0 \\ Selections from a Sung Dynasty Poet}

\section{Burton Watson, Translator}

The people of the Sung dynasty, of which Su Tung-p'o is the greatest poet, had a way of life, values, and interests which have much in common with modern Western man. Consequently, Sung poetry seems to the Western reader very similar to that of his contemporaries. These selections record the poet's experiences, express his griefs and joys, and paint vivid word pictures of people and scenes.

$\$ 3.75$

\section{THE MAHĀBHĀRATA An English Version Based on Selected Verses}

\section{Chakravarthi V. Narasimhan}

A Sanskrit classic, and one of India's two great epics, the Mahābhārata is the longest and one of the greatest epic poems written in any language. The main narrative is the story of the rivalry between the cousins of two families which culminates in the great battle of Kuruksetra. In spite of its many episodes of weakness, violence, and revenge, the essential theme of the epic is peace and reconciliation.

$\$ 6.00$

\section{COLUMBIA}




\title{
COLUMBIA
}

\section{REFORMER IN MODERN CHINA Chang Chien: 1853-1926}

\author{
Samuel C. Chu
}

Among the men who advocated a substantive program of modernization in nineteenth-century China, Chang Chien was one of the most successful yet least known. He was almost solely responsible for the transformation of Nan-T'ung, his native district and an undeveloped, unproductive region, into a model district. His career and accomplishments illustrate the interaction between the forces of progress and reaction in nineteenth-century China, and reflect the problems faced by modernizers in all parts of the world.

$\$ 6.00$

\section{TWENTIETH CENTURY CHINA}

\section{O. Edmund Clubb}

"This excellent book will force its readers to think carefully about China's place in the world and how other nations must adjust to China's dynamic and dangerous revolution. . . . In no other work in English will one find a more graphic, more brutally realistic account of the power struggles that have racked China from the days of Yuan Shih-k'ai to those of Mao Tse-Tung, nor of the conflicts between China, Japan, Russia and the United States to shape the future of eastern Asia."-New York Times Book Review

cloth $\$ 7.95$; paper $\$ 2.75$

COLUMBIA UNIVERSITY PRESS

2960 Broadway

New York, N. Y. 10027

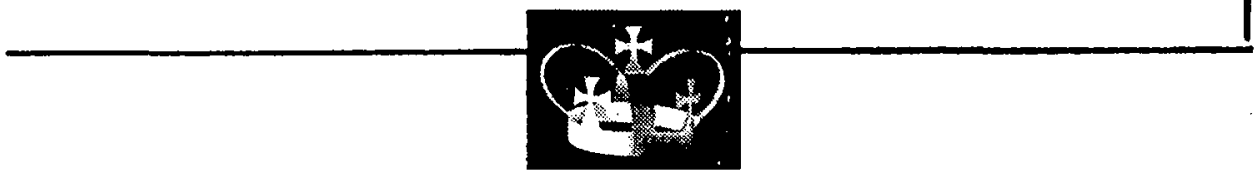




\section{REFERENGE WORKS on the FAR EAST}

Library Catalogue of the

School of ORIENTAL and AFRICAN STUDIES, University of London

Each of the 14 sections of the catalog is available separately.

554,000 cards, 28 volumes complete

Price: $\$ 1600.00$

Dictionary Catalog of the ORIENTAL COLLECTION

The New York Public Library

318,500 cards, 16 volumes

Price: $\$ 960.00$

\section{Index to LEARNED CHINESE PERIODICALS}

East Asian Library, Columbia University

4,500 cards, 1 volume

Price: $\$ 35.00$

INDIA OFFICE Library, Commonwealth Relations Office, London Catalogue of European Printed Books

110,000 cards plus sheaf entries, 10 volumes

Price: $\$ 535.00$

Index of Post-1937 European Manuscript Accessions

3,200 cards, 1 volume

Price: $\$ 35.00$

Catalogue of the COLONIAL OFFICE Library

187,000 cards plus sheaf entries, 15 volumes

Price: $\$ 875.00$

Research Catalogue of the AMERICAN GEOGRAPHICAL SOCIETY

Each of the eight sections of the catalog is available separately.

219,000 cards, 15 volumes complete

Price: $\$ 865.00$

Index to Periodical Articles, 1950-1964, in the Library of The ROYAL INSTITUTE of INTERNATIONAL AFFAIRS

Approximately 30,000 cards, 2 volumes

Prepublication price: $\$ 100.00$; after July $31,1965: \$ 125.00$

$10 \%$ additional charge on orders outside the U.S.

Descriptive material on these titles and a complete catalog of publications

are available on request.

G. K. HALL- \& CO. 70 Lincoln Street, Boston, Mass. 02111 


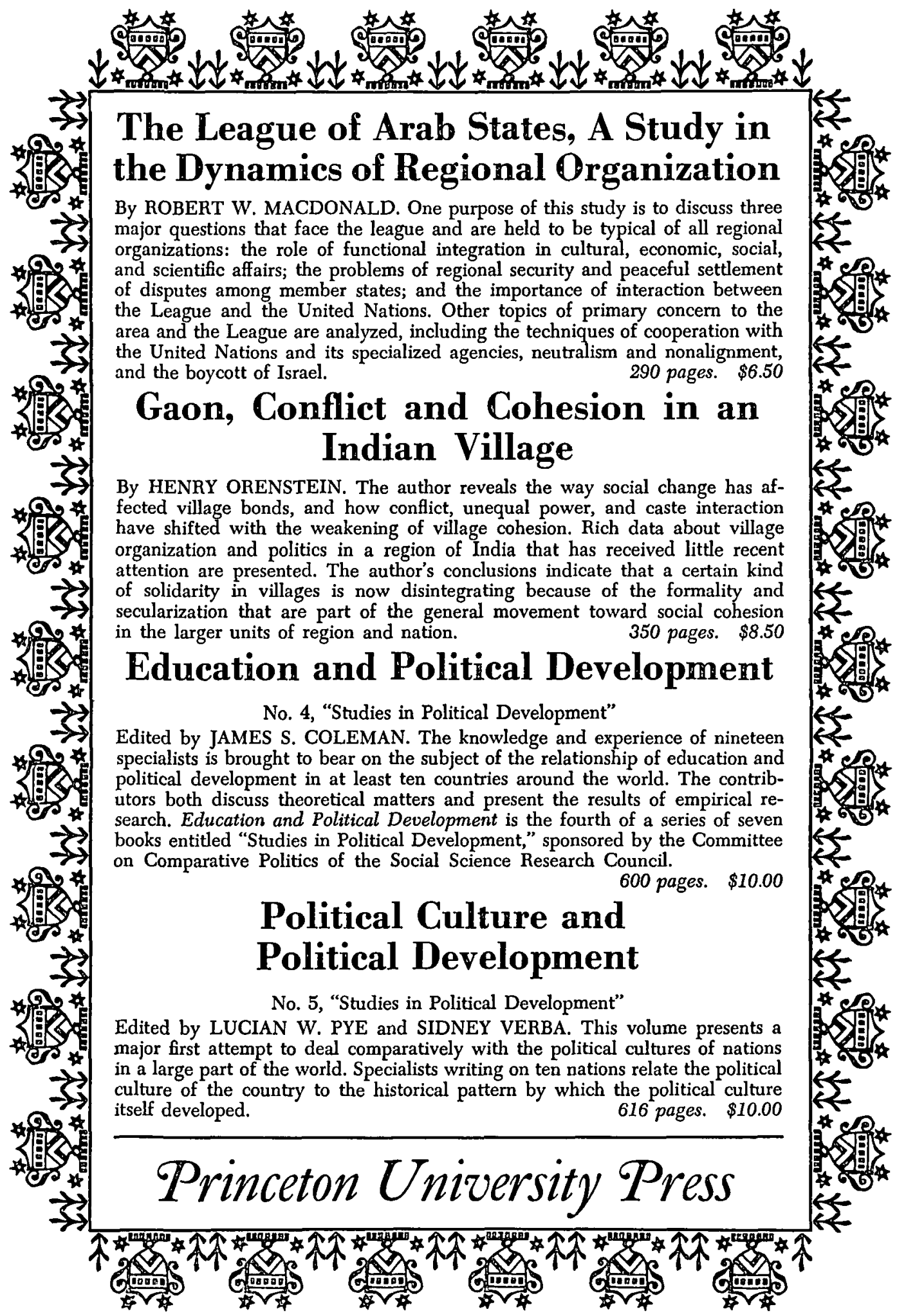




\section{Between Two Empires}

THE ORDEAL OF THE PHILIPPINES, 1929-1946

by Theodore Friend

Based on extensive documentary research and numerous interviews in all three countries, this is the first study in depth of the Philippines' relationship with the United States and Japan during the years 1929 to 1946. Mr. Friend delineates in fascinating detail the fight for independence led by Manuel Quezon, Sergio Osmeña, and Manuel Roxas. He follows these and other Filipino leaders through the period of Japanese occupation and American liberation to the day in 1946 when the Philippines became the first Asian colony to achieve sovereignty.

$\$ 7.50$

\section{A New China Policy}

SOME QUAKER PROPOSALS

A Report Prepared for the American Friends Service Committee

Prepared by a group of Quaker scholars and specialists on China, this informed analysis of the serious issues involved in the relationship between the United States and the People's Republic of China and these proposals for the future are bound to attract wide attention and compel both concerned citizens and government officials to take a fresh look at a critical situation.

cloth $\$ 3.00$; paper $\$ .95$

\section{Fenollosa: The Far East and American Culture}

by Lawrence W. Chisolm

"The result of meticulous research and thinking by a conscientious scholar, probably not to be duplicated or surpassed until new materials about Fenollosa are found .... an indispensable work for scholars interested in Fenollosa and early American-Eastern cultural relations."-The Asian Student.

$\$ 7.50$

\section{Conspiracy at Mukden}

THE RISE OF THE JAPANESE MILITARY

by Takehiko Yoshihashi

On the basis of evidence in the dossiers of the Tokyo War Crimes Trials and memoirs of Japanese statesmen, Mr. Yoshihashi develops the thesis that the Mukden Incident was engineered by civilian as well as military extremists. "Of interest and value to students of both China and Japan ... an important case study for those who seek to comprehend the growing number of military coups in the modern world."-Ralph L. Powell.

$\$ 6.50$

\section{The Archaeology of Ancient China}

by Kwang-chih Chang

"A highly interpretive and closely integrated work ... the best single volume on the archaeology and civilization of ancient China."-Journal of Asian Studies.

$\$ 10.00$

\section{Toward Economic Cooperation in Asia}

by David Wightman

"A thoroughly professional piece of work, yet fully understandable to the reader who lacks a degree in economics. Mr. Wightman's book is a significant contribution to the literature of 'underdevelopment', equally welcome to the student, the politician, and the administrator."-Times Literary Supplement.

\section{Y A Yale University Press




\title{
A HISTORY OF EAST ASIAN CIVILIZATION
}

\author{
EAST ASIA: THE GREAT TRADITION \\ Volume I of a HISTORY OF ASIAN CIVILIZATION \\ Edwin O. Reischauer and John K. Fairbank
}

An account of East Asian civilization as it developed over three millenniums from its beginnings in North China up to the early nineteenth century. Remarkable for several reasons, this book ( 1 ) gives an over-all picture of institutional and cultural growth, (2) achieves balance and integration among economic, political, intellectual, and cultural factors, (3) draws fruitful comparisons and relationships between historical developments in the major East Asian countries, and also between these and the rest of the world, (4) offers a number of new concepts and interpretations which put new meaning into many aspects of East Asian history, (5) provides ample, relevant illustrations.

739 pages

1960

$\$ 8.95$

\section{EAST ASIA: THE MODERN TRANSFORMATION}

\section{Volume II of A HISTORY OF EAST ASIAN CIVILIZATION}

John K. Fairbank, Edwin O. Reischauer, and Albert M. Craig

The long-awaited second volume of this widely-used text brings the history of the "Chinese culture area" down to the present decade. Modernization, beginning as a response to the Western impact, is viewed in the perspective of the traditional development of the societies and cultures of China, Japan, Korea, and the peripheral areas, including Southeast Asia and Inner Asia. The contrasting experiences of the Chinese and Japanese peoples in modern times provide a central theme. The 80 plates, 45 maps, numerous line cuts, charts and tables of this attractive volume help to set a new standard of comprehensiveness. Index 57 pages.

976 pages

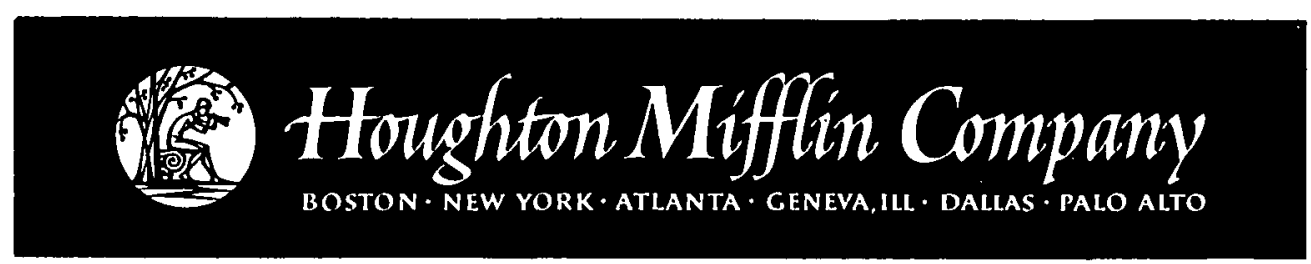


Announcing the

Summer 1965 Issue

\section{Journal of \\ INTERNATIONAL AFFAIRS}

\section{MEDITERRANEAN EUROPE:}

Problems and Possibilities

Rich and Poor Nations in Economic Integration

Labor Migrations: Impact and Incidence

Catholicism and the Problems of Rural Community

Economic and Social Changes

in South West France, Greece, Southern Italy,

Portugal, Spain and Yugoslavia

Order from:

JOURNAL OF INTERNATIONAL AFFAIRS

Columbia University

Department 700

409 West 117th Street

New York, N. Y. 10027, U. S. A. 


\section{The Taiping Rebellion}

VOLUME I: THE HISTORY

By Franz Michael. This first full history and analysis of a mid-nineteenth-century totalitarian movement is of major importance for all who would understand developments in China over the past one hundred years. 256 pages, 15 maps. $\$ 7.50$

\section{Conciliation and Japanese Law}

TOKUGAWA AND MODERN

By Dan Fenno Henderson. In this new study Professor Henderson systematically investigates the nature of traditional Japanese conciliation, both in and out of the Tokugawa courts, and its accommodation into the modern legal system. 484 pages. Two volumes. $\$ 15.00$ the set

\section{Court and Constitution in Japan}

SELECTED SUPREME COURT DECISIONS, 1948-60

By John M. Maki. "Professor Maki's book . . . will provide the Western student with invaluable materials for the study of the Japanese legal system."-Journal of Asian Studies. 491 pages. $\$ 9.50$

\section{A Manual of Spoken Tibetan}

By Kun Chang and Betty Shefts. This instructional manual of spoken Tibetan (Lhasa Dialect) is the first based on modern linguistic techniques. 300 pages. $\$ 6.50$

Accompanying tapes prepared by native speakers. Two 7" reels, approximately four hours. $\$ 17.50$ the set

\section{Basic Japanese for College Students}

By Tamako Niwa and Mayako Matsuda. An entirely romanized text for rapid teaching of spoken Japanese and grammar at the college level. 632 pages, illus. $\$ 8.95$

\section{AVietnamese Reader}

By Lawrence Thompson and Nguyen duc Hiep. This text will enable the student with a knowledge of spoken Vietnamese to read newspapers, technical material, and literary writings. 272 pages. $\$ 3.50$ 


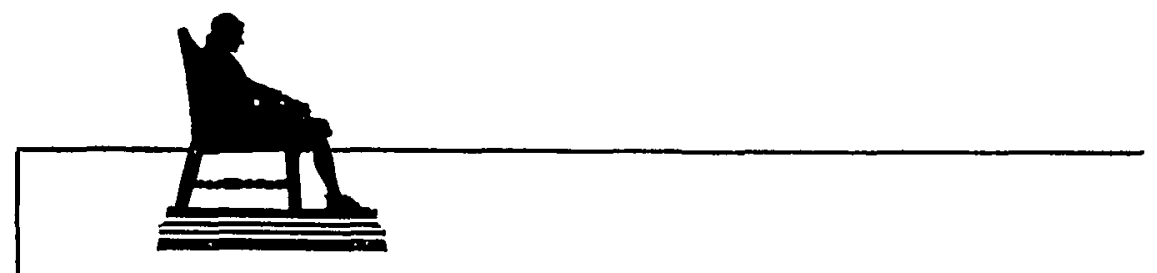

\section{A THOUSAND LIVES AWAY}

Buddhism in Contemporary Burma By WINSTON L. KING

An absorbing and authoritative account of the attempt of an ancient traditional religion to confront the modern world meaningfully. The author includes a new analysis of meditation and the complicated Buddhist cosmology, and an explanation of how the varieties of Buddhism form an organic unity in contemporary Burma. $\$ 5.25$

\section{AN ANTHOLOGY OF}

\section{SANSKRIT COURT POETRY}

Vidyakara's Subhasitaratnakosa

Translated by DANIEL H. H. INGALLS

Here in vivid translation are the 1739 lovely and moving verses from the recently discovered Sanskrit anthology of Vidyakara. Mr. Ingalls includes separate essays on the style and conventions' of the poetry, and provides the first general criticism by a Western scholar of the techniques and aims of Classical Sanskrit poetry. Harvard Oriental Series, 44. $\$ 15.00$

\section{STUDIES IN CHINESE LITERATURE} Edited by JOHN L. BISHOP

Here is a collection of eight basic studies on Chinese literature, ranging from the Six Dynasties period (222-589 A.D.) to the 17 th century, including studies of poetry, prose styles, and colloquial fiction. Harvard-Yenching Institute Studies, 21. Paperbound. $\$ 4.50$

\section{MODERN JAPANESE: A BASIC READER} By HOW ARD S. HIBBETT and GEN IT ASAKA

This textbook is designed to offer a rapid but thorough introduction to modern Japanese for students who have already acquired a sound grasp of the fundamentals of the spoken language. The text prepares the student to read directly from current Japanese publications. Two volumes, paperbound. $\$ 7.50$ 


\section{THE UNITED STATES AND JAPAN}

Third Edition

BY EDWIN O. REISCHAUER

A completely revised and enlarged edition of a book Political Science Quarterly considered "by far the most important interpretation of Japan written since the war." The U.S. Ambassador to Japan presents a vivid, incisive analysis of Japan's relations with the West, and defines the changes being wrought by a new generation. American Foreign Policy Library. $\$ 6.50$

\section{THE CHRONICLE OF THE THREE KINGDOMS,}

\section{Volume II}

Translated by ACHILLES FANG

Edited by BERNARD S. SOLOMON

This volume continues the detailed account of events in China from 220-265 A.D., translated from the celebrated history Tzu-chih t'ung-chien. With Volume I, this work constitutes a complete demonstration of the Chinese method of compiling general histories. Harvard-Yenching Institute Studies, 6. Paperbound. $\$ 15.00$

\section{THE CHINESE RED ARMY, 1927-1963}

An Annotated Bibliography

By EDW ARD J. M, RHOADS

An invaluable guide to research into the army's role in China, this bibliography of the literature dealing with the Chinese Red Army from its beginnings to the present includes about 600 items, chiefly books, pamphlets, and articles from military and scholarly journals in several languages. Distributed for the East Asian Research Center, Harvard University. Paperbound. $\$ 3.25$

\section{CHINESE COMMUNISM AND THE RISE OF MAO} BY BEN] AMIN I. SCHW ARTZ

"A towering piece of research, a study so important that it must be read by everyone concerned with Chinese Communism ... will remain a standard reference for years to come."-Chicago Tribune. "Mr. Schwartz's account is illuminating and Far East scholars are in his debt."Political Science Quarterly. Russian Research Center Studies, 4. Fifth printing. $\$ 5.00$

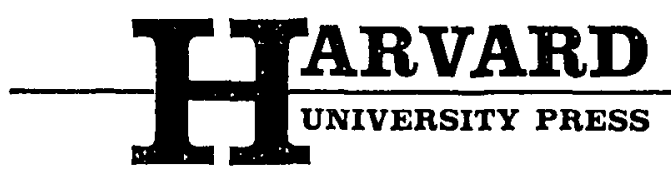




\section{new titles of asian interest}

\section{from california}

\section{INTER-ECONOMY COMPARISONS}

A Case Study. Leonard A. Doyle. Attempts to compare the investment requirements and operating costs of a modern large-scale manufacturing plant in a developing economy with those of a generally similar plant in an industrial economy. The two enterprises are a government cement plant in Indonesia and a private cement plant in the U. S.

$\$ 6.00$

\section{RUSSIA'S HAWAIIAN ADVENTURE, 1815-1817}

Richard A. Pierce. This account of a little-known attempt to secure the Hawaiian Islands for Russia provides fresh material on the early history of the newest statesHawaii and Alaska-and offers insights into international relations in the Pacific basin during the early 19th century.

$\$ 5.50$

\section{CONFUCIAN CHINA AND ITS MODERN FATE}

Volume Three: The Problem of Historical Significance. Joseph R. Levenson. With this book, Mr. Levenson concludes his penetrating and eloquent study of modern China in relation to the Confucian past.

$\$ 5.00$

\section{MINOBE TATSUKICHI:}

Interpreter of Constitutionalism in Japan. Frank O. Miller. “Mr. Miller's study of Minobe will immediately become a standard work on constitutional thought in twentieth-century Japan."--Marius Jansen

A Publication of the Center for Japanese and Korean Studies

$\$ 7.50$

\section{THAI PEASANT PERSONALITY}

The Patterning of Interpersonal Behavior in the Village of Bang Chan. Herbert $\mathbf{P}$. Phillips. This first book-length study of Siamese psychological life describes the members of an Asian peasant community whose dominant personality traits are aimed at the maintenance of their individuality, privacy, and sense of self-regard.

$\$ 6.00$

\section{THE EMERGENCE OF AN INDUSTRIAL LABOR FORCE IN INDIA}

A Study of the Bombay Cotton Mills, 1854-1947. Morris David Morris. Examines the view that rural attachments in India made it difficult to generate a stable factory work force attuned to modern industry. The Bombay cotton textile industry is shown to have easily created the labor force it needed. Difficulties arose, not from the persistence of rural values, but from the economic organization of the industry itself.

$\$ 6.50$

\section{TWENTY-SIX CENTURIES OF AGRARIAN REFORM}

A Comparative Analysis. Elias H. Tuma. Questions whether land reform movements have ever accomplished their main goals of redistributing wealth, encouraging economic development, improving the over-all standard of living, and ensuring political stability.

$\$ 7.00$

\section{ANCIENT INDO-EUROPEAN DIALECTS}

Edited by Henrik Birnbaum and Jaan Puhvel. The first book to provide a rigorous and comprehensive view of the linguistic divisions of early Europe, Asia Minor, Northern India, and Chinese Turkestan. $\$ 12.00$

\section{university of california press} berkeley $\cdot$ los angeles $\cdot$ new york 


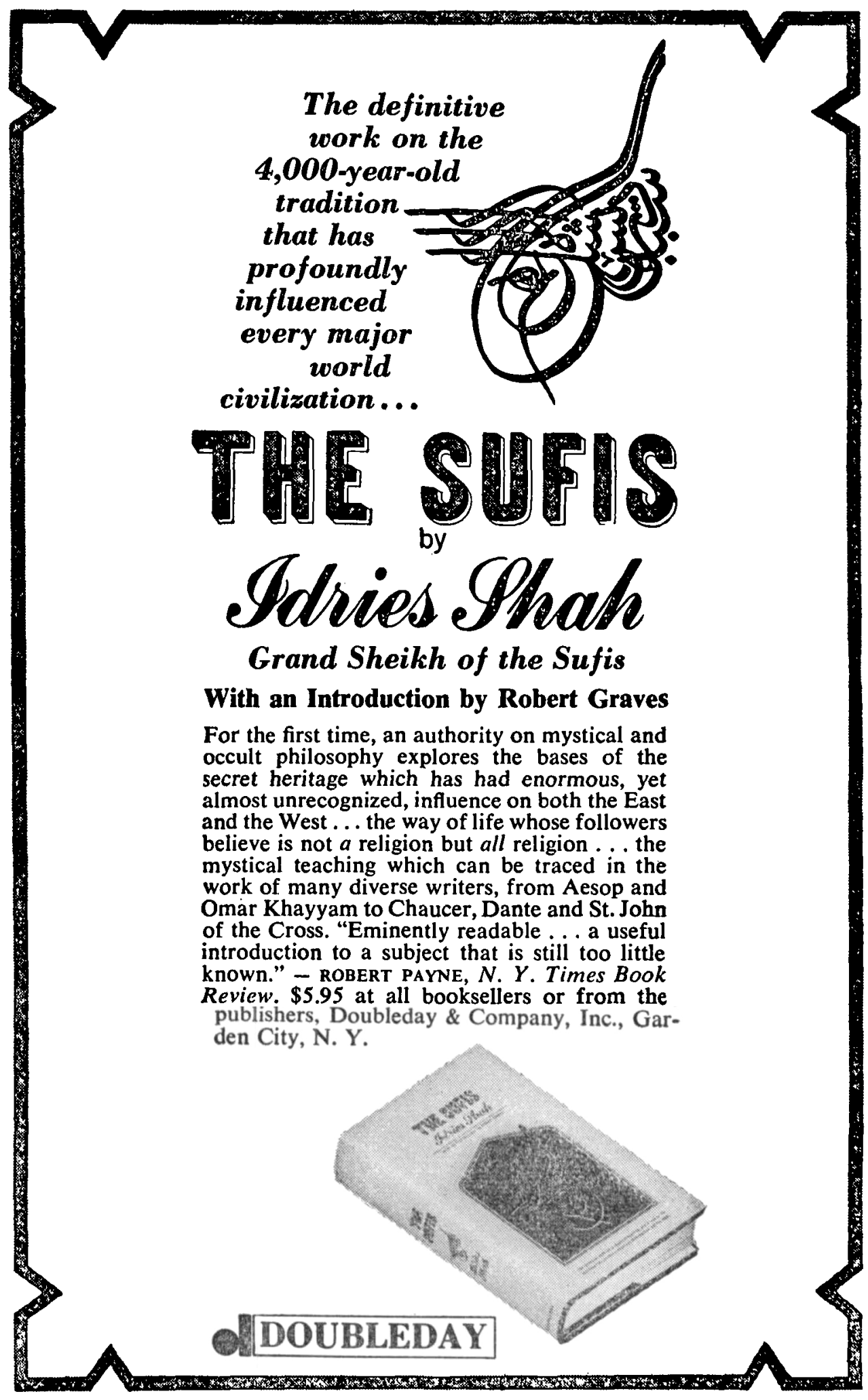




\section{United States Policy and the Partition of Turkey, 1914-1924}

By Laurence Evans. The author makes a detailed and thoroughly documented study of the phases through which American Middle East policy passed during and following World War I. He presents the problems facing the United States-primarily from the viewpoints of the President and Secretary of State-as its policy went from complete non-involvement to intense concern and back to noninvolvement.

From bookstores or from

\section{The Johns Hopkins Press}

Baltimore, Maryland 21218

\section{MAHFIL}

(A Quarterly in English)

Poetry Fiction Essays from

India \& Pakistan Annual: $\$ 2.50$ Sample Copy : $75 \$$

Box 39, Foster Hall, University of Chicago, Chicago 37, Illinois 


\section{ASIAN SURVEY}

Leading American monthly devoted exclusively to current developments in Asia. Coverage of political, economic and social trends in such societies as Communist China, India, Japan, Pakistan, Korea, Indonesia, and Burma.

In recent issues, ASIAN SURVEY articles have analyzed such topics as the Congress System in India, North Vietnam in the Sino-Soviet dispute, Japan's Relations with Communist China, and the Sukarno regime and the PKI. Eminent Asian and Western scholars contribute to this journal.

In addition to the regular issues, subscribers receive two structured issues in January and February surveying trends for the previous year throughout East and South Asia.

Rates: $\$ 6$ per year for 12 issues ( $\$ 7$ for overseas subscribers). Special student rate: $\$ 3$ per year. ASIAN SURVEY, University of California, 2538 Channing Way, Berkeley, California 94720.

\section{THE DEVELOPING ECONOMIES \\ Quarterly Journal \\ of}

\section{The Institute of Asian Economic Affairs}

42 Ichigaya-Hommura-cho, Shinjukn-ku, Tokyo, Japan

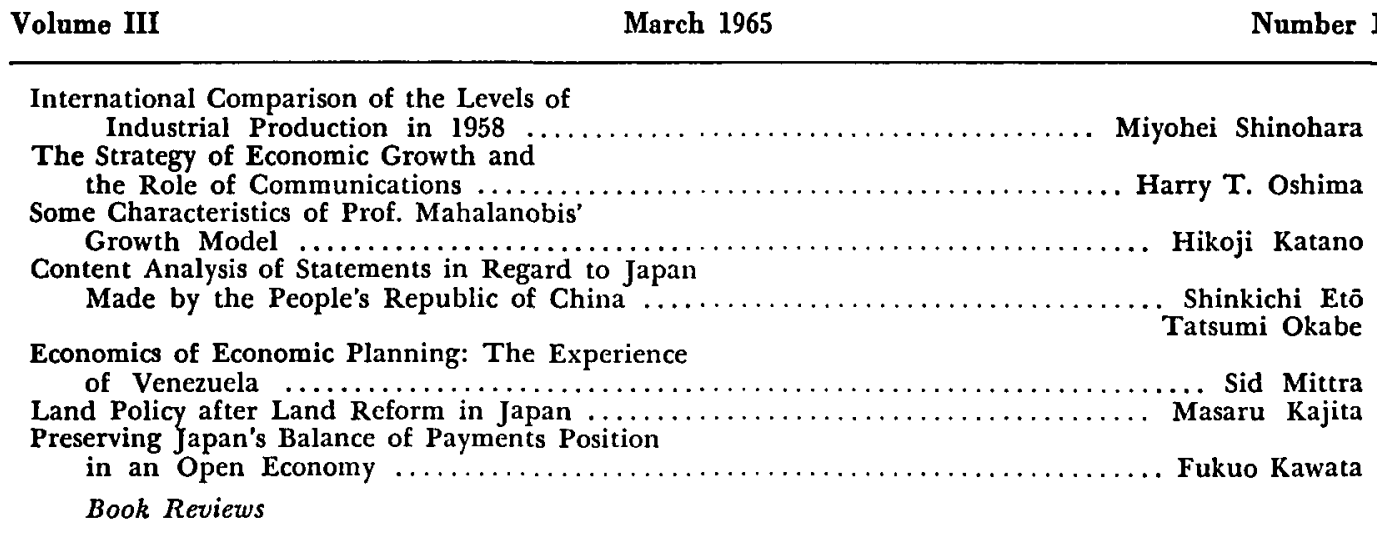

Single copies: $\$ 2.00$ (post free)

Subscription price ( 4 issues) : $\$ 7.50$ (post free)

Orders may be sent to the sole agent,

MARUZEN COMPANY, LTD.

P. O. Box 605, Tokyo Central, Tokyo, Japan 


\section{ANNOUNCEMENT}

The eighteenth annual meeting of the Association for Asian Studies will be held at the Americana Hotel, New York, April 4-6, 1966.

The nineteenth annual meeting of the Association for Asian Studies will be held at the Palmer House, Chicago, March 20-22, 1967. 


\section{EAST-WEST CENTER PRESS - HONOLULU}

Spring-Summer 1965 Books

EDUCATION AND DEVELOPMENT

STRATEGY IN SOUTH AND

SOUTHEAST ASIA

By Muhammad Shamsul Huq

July $\$ 7.00$

\section{THE CHALLENGE OF INDUSTRIAL RELATIONS IN PACIFIC-ASIAN COUNTRIES}

Edited by Harold S. Roberts

August $\$ 6.50$

\section{A STUDY OF LAND REFORMS IN UTTAR PRADESH}

By Baljit Singh and Shridhar Misra Now Ready $\$ 5.00$

KRISHNA: Myths, Rites, and Attitudes

Edited by Milton Singer

August \$5.50

CHINESÉ PHILOSOPHY, 1949-1963:

An Annotated Bibliography of

Mainland Chine Publications

By Wing-tsit Chan

June Paper $\$ \mathbf{7} .50$

TEACHING ENGLISH AS A SECOND LANGUAGE: A Selected

Bibliography

By Yao Shen and Ruth Crymes Now Ready Paper $\$ 3.50$

ENGLISH MONOSYLLABLES: A Minimal Pair Locator List for Teaching English as a Second Language

By Ted Plaister

Now Ready Paper \$1.25
Previously

Announced

THE MAHARASHTA PURANA An Eighteenth-Century Bengali Historical Text

Translated, annotated, and with an introduction by Edward C. Dimock, Jr., and Pratul Chandra Gupta May $\$ 5.00$

WAYS OF THINKING OF EASTERN PEOPLES: India, China, Tibet, Japan, Revised Edition

b̀y tiajime ìaküriatu

Edited by Philip P. Wiener

Now Ready $\$ 9.50$

BINODIN!: A Novel

By Rabindranath Tagore

Now Ready $\$ 5.00$

FORMS IN JAPAN

by Yuichiro Kojiro

Translated by Kenneth Yasuda

Photographs by Yukio Futagawa

May $\$ 15.00$ 